\title{
New Spectrophotometric Method for the Determination of Bosentan - An Anti-Hypertensive Agent in Pharmaceutical Dosage Forms
}

\author{
A. NARENDRA* ${ }^{*}$ D. DEEPIKA ${ }^{\#}$ AND M. MATHRUSRI ANNAPURNA ${ }^{\S}$ \\ *Department of Pharmaceutical analysis and Quality Assurance, Roland Institute of \\ Pharmaceutical Sciences, Berhampur, Orissa, India. \\ "Royal College of Pharmacy and Health Sciences, Berhampur, Orissa,, India. \\ ${ }^{\S}$ GITAM Institute of Pharmacy, GITAM University, Visakhapatnam, India. \\ naren_angirekula@yahoo.com
}

Received 23 July 2011; Accepted 20 September 2011

\begin{abstract}
A new, simple and sensitive spectrophotometric method in ultraviolet region has been developed for the determination of Bosentan in bulk and in pharmaceutical formulations. Bosentan exhibits absorption maxima at $273 \mathrm{~nm}$ with apparent molar absorptivity of $1.3293 \times 10^{4} \mathrm{~L} / \mathrm{mol} . \mathrm{cm}$ in methanol and octane 1-sulfonic acid solvent mixture. Beer's law was found to be obeyed in the concentration range of $0.1-100 \mu \mathrm{g} / \mathrm{mL}$. The method was validated as per the ICH guidelines.
\end{abstract}

Keywords: Bosentan, Methanol, Octane-1-sulfonic acid, ICH.

\section{Introduction}

Bosentan $^{1} \quad$ (BST) is chemically, 4-tert-butyl- $N$-[6-(2-hydroxyethoxy) -5- (2methoxyphenoxy) -2- (pyrimidin-2-yl) pyrimidin-4-yl] benzene-1 sulfonami- de (Figure 1). It has a molecular formula, $\mathrm{C}_{27} \mathrm{H}_{29} \mathrm{~N}_{5} \mathrm{O}_{6} \mathrm{~S}$ with molecular weight 551.614 .

Bosentan (BST) is a dual endothelin receptor antagonist important in the treatment of pulmonary artery hypertension. Bosentan is used to treat pulmonary hypertension by blocking the action of endothelin molecules that would otherwise promote narrowing of the blood vessels and lead to high blood pressure. Endothelin-1 (ET-1) is a neurohormone, the effects of which are mediated by binding to $\mathrm{ET}_{\mathrm{A}}$ and $\mathrm{ET}_{\mathrm{B}}$ receptors in the endothelium and vascular smooth muscle. ET-1 concentrations are elevated in plasma and lung tissue of patients with pulmonary arterial hypertension, suggesting a pathogenic role for ET -1 in this disease. Bosentan is a specific and competitive antagonist at endothelin receptor types $\mathrm{ET}_{\mathrm{A}}$ and $\mathrm{ET}_{\mathrm{B}}$. Bosentan has a slightly higher affinity for $\mathrm{ET}_{\mathrm{A}}$ receptors than for $\mathrm{ET}_{\mathrm{B}}$ receptors. ET is present in astrocytes and neurons, endothelial / epithelial cells and certain smooth muscle cells, and can mediate both, endothelium-dependent relaxation, vasoconstriction, and 
brochoconstriction. Metabolism of bosentan (I) occurs mainly in the liver by the action of cytochrome P (CYP) 450 3A4 and 2C9, which produces three metabolites: the hydroxy lated (hydroxy) metabolite (II), the demethylated (phenol) metabolite (III), and the hydroxylated and demethylated (hydroxy-phenol) metabolite (IV) ${ }^{2-6}$.

Bosentan is not official in any pharmacopoeia. On detailed literature survey it is found that very few HPLC ${ }^{7-10}, \mathrm{LC}_{-M S}{ }^{11}$ and spectrophotometric ${ }^{12-15}$ methods were developed for the determination of Bosentan. The aim of the present work is to develop new spectrophotometric method for the determination of BST in pharmaceutical dosage forms and to validate as per ICH guidelines ${ }^{16}$.

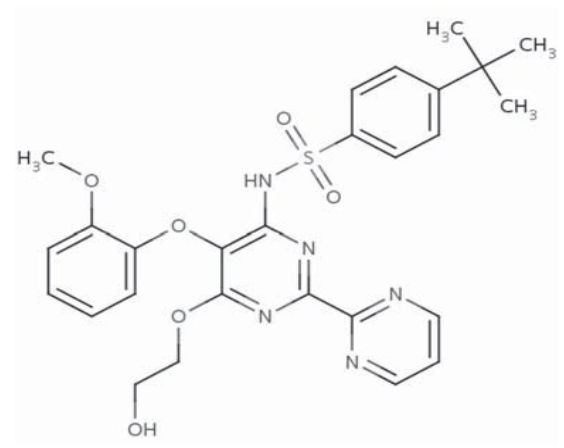

Figure 1. Chemical structure of Bosentan (BST).

\section{Experimental}

Apparatus

All spectral study was performed using a double beam UV-VIS spectrophotometer (UV1800, Shimadzu, Japan) was employed with a pair of $10 \mathrm{~mm}$ matched quartz cells.

\section{Chemicals and reagents}

Methanol (AR) (Merck), octane-1 sulfonic acid sodium salt (Spectrochem Pvt. Ltd.) and ortho phosphoric acid (AR) (Merck) were used in the present study. Bosentan (BST) was obtained from Cipla Ltd. (India) and was used as such without further purification.

\section{Recommended procedure and calibration curve}

Preparation of stock solution

BST (25 mg) was accurately weighed and dissolved in methanol in a $25 \mathrm{~mL}$ volumetric flask to prepare stock solution $(1000 \mu \mathrm{g} / \mathrm{mL})$.

Preparation of buffer solution

4.35 grams of octane 1- sulfonic acid was dissolved in $800 \mathrm{ml}$ of water and the $\mathrm{pH}$ was adjusted to 3.5 with o-phosphoric acid in a $1000 \mathrm{ml}$ volumetric flask.

The stock solution was further diluted suitably with methanol and octane 1-sulfonic acid $(\mathrm{pH}$ 3.5) $(50: 50 \mathrm{v} / \mathrm{v})$ solvent mixture to get a working standard solution $(100 \mu \mathrm{g} / \mathrm{mL})$. A series of solutions $(0.1-100 \mu \mathrm{g} / \mathrm{ml})$ were prepared and scanned against reagent blank. The absorption maximum was recorded as $273 \mathrm{~nm}$ (Figure 2) and the absorbance values of all the above mentioned solutions were noted at that $\lambda_{\max }$. A calibration curve of BST was plotted with 
concentration of the drug solution on the $\mathrm{x}$-axis and the corresponding absorbance values on the y-axis.

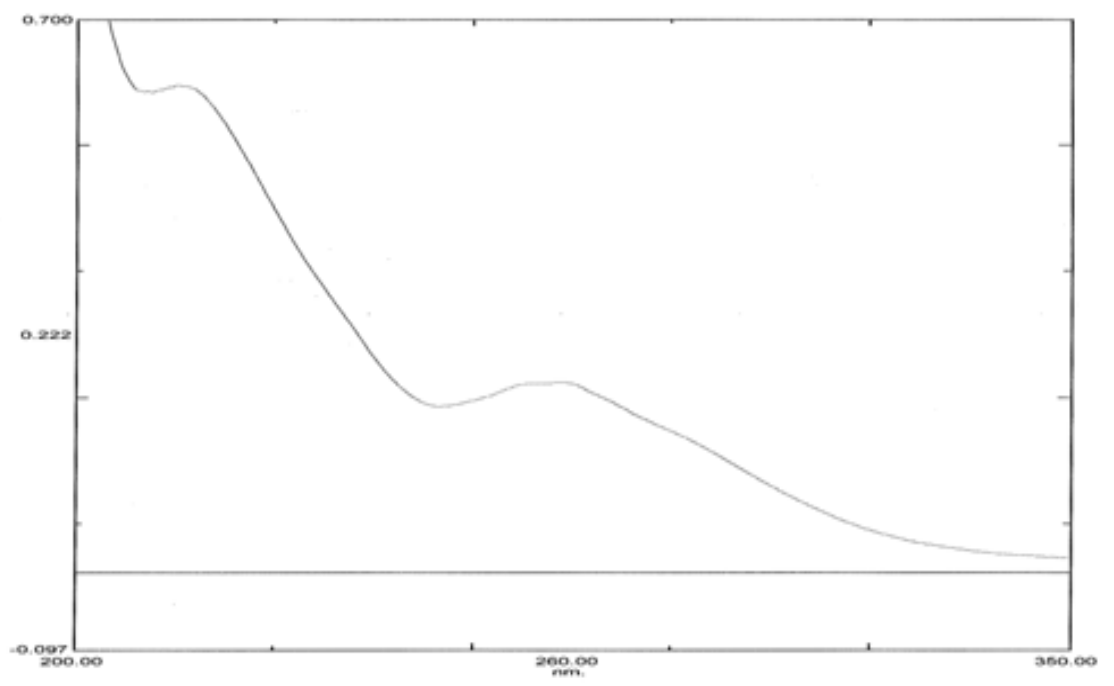

Figure 2. Absorption spectrum of Bosentan $\left(10 \mu \mathrm{g} \mathrm{ml}^{-1}\right)$.

\section{Assay Procedure for tablets}

Bosentan gift sample was supplied by Cipla Laboratories (India) and the commercial formulations available are BOSENTAS $(62.5 \mathrm{mg}$ and $125 \mathrm{mg})$, BOZETAN (62.5 $\mathrm{mg}$ and $125 \mathrm{mg}$ ) and LUPIBOSE (62.5 mg and $125 \mathrm{mg}$ ) and were purchased from the local market.

Twenty tablets were finely powdered and powder equivalent to $25 \mathrm{mg}$ of Bosentan was extracted with methanol, sonicated for half an hour and filtered through Whatman $0.42 \mathrm{~mm}$ filter paper and suitable dilutions were made from the filtrate as described earlier in a $25 \mathrm{ml}$ volumetric flask and analyzed against reagent blank.

\section{Precision}

The Inter-day precision was determined on three different days at three different levels (10, 20 and $\left.50 \mu \mathrm{g} \mathrm{mL}^{-1}\right)$ and the Intraday precision was determined at three different levels $(10$, 20 and $50 \mu \mathrm{g} \mathrm{mL}^{-1}$ ) by the same analyst.

\section{Accuracy}

Recovery studies were carried out by adding different amounts $(80 \%, 100 \%, 120 \%)$ of bulk samples of BST to the pre-analyzed formulation and the mixture was analyzed for the drug content using the proposed method. The percentage recovery was calculated.

\section{Results and Discussion}

Bosentan obeys Beer-Lambert's law in the concentration range of $0.1-100 \mu \mathrm{g} / \mathrm{ml}$. The optical characteristics were given in Table 1. 
Table 1. Optical characteristics of BST.

\begin{tabular}{lc}
\hline Parameters & Values \\
\hline Beer-Lambert's range $(\mu \mathrm{g} / \mathrm{ml})$ & $0.1-100$ \\
$\lambda_{\max }(\mathrm{nm})$ & 273.0 \\
Molar extinction coefficient $^{-1}$ Litre $\left.\mathrm{mol}^{-1} \mathrm{~cm}^{-1}\right)$ & \\
${\text { Sandell sensitivity }\left(\mu \mathrm{g} / \mathrm{cm}^{2} / 0.001 \text { absorbance unit) }\right.}$ & $1.3293 \times 10^{4}$ \\
& \\
Regression equation & 0.04149 \\
Slope (a) & $\mathrm{y}=\mathrm{ax}+\mathrm{b}$ \\
Intercept $(\mathrm{b})$ & 0.025 \\
Correlation coefficient $(\mathrm{r})$ & 0.007 \\
\hline
\end{tabular}

The $\%$ RSD values in precision study were found to be in the range $0.347-0.698$ (Intraday) and $0.632-0.901$ (Interday) which are less than $2 \%$ indicating that the method is more precise. The \% RSD values in accuracy study were found to be less than $2 \%(0.831-1.052$ \%) indicating that the method is more accurate. Therefore the present methods can be employed for the estimation of Bosentan in pharmaceutical formulations successfully. The statistical analysis of commercial formulations has been shown in Table 2.

Table 2. Analysis of commercial formulations (Tablets).

\begin{tabular}{ccccc} 
S. No & Formulation & $\begin{array}{c}\text { Labeled claim } \\
(\mathrm{mg})\end{array}$ & $\begin{array}{c}\text { Amount found } \\
(\mathrm{mg})\end{array}$ & $\begin{array}{c}\text { \% Label claim } \pm \\
\text { SD* }\end{array}$ \\
\hline 1 & Brand I & 62.5 & 62.478 & $99.96 \pm 0.121$ \\
\hline 2 & Brand II & 62.5 & 62.439 & $99.90 \pm 0.312$
\end{tabular}

*Average of six determinations.

\section{Conclusions}

The present method is simple, precise, accurate and can be employed for the determination of Bosentan in pharmaceutical formulations successfully.

\section{Acknowledgements}

Authors are grateful to Chandra Labs, Hyderabad for providing research facilities and to Cipla Ltd. India for providing gift samples.

\section{References}

1. The Merck Index, An Encyclopedia of Chemicals, Drugs and Biologicals, Maryadele J.O' Neil. Eds, $14^{\text {th }}$ Ed., Published by Merck Research Laboratories, Division of Merck and Co. Inc., Whitehouse Station, NJ, 2006, 221.

2. Weber C, Gasser R and Hopfgartner G, Drug Metab. Dispos. 1999, 27, 810.

3. Weber C, Schmitt R, Birnboeck H, et al. Clin Pharmacol Ther. 1996, 60, 124. 
4. Weber C, Schmitt R, Birnboeck H, Hopfgartner G, Clin. Pharmacol. Ther. 1996, 60, 124.

5. Weber C, Schmitt R, Birnboeck H, Hopfgartner G and Eggers H, J. Clin. Pharmacol. 1999, 39, 703.

6. Weber C, Banken L, Birnboeck H, Nave S, Schulz R, Br.J. Clin. Pharmacol. 1999, 47, 701.

7. Dell D, Lausecke Br, Hopfgartner G, Van Giersbergen PLM, Dingemanse $J$. Chromatographia., 2002, 55 (Supplement 1), S115.

8. Lausecker B, Hess B, Fiscer G, Mueller M, Hopfgartner G, J Chromatogr B Biomed Sci Appl., 2000, 749 (1), 67.

9. Karnaker Reddy T, Younus MD, Ravindra Reddy Y, Ashwini Kumar G, Sravan S. Int J Pharm Tech., 2010, 2 (3), 577.

10. Rajendran S D, Philip B K, Gopinath R and Suresh B, Indian journal of pharmaceutical sciences, 2007, 69, 796.

11. Lausecker B and Hopfgartner G, J. Chromatogr. A., 1995, 712, 75

12. Mathrusri Annapurna M, Souvik Das, Narendra A and Raja Kumar V, J Pharm Educ Res., 2010, 1, 73.

13. Mathrusri Annapurna M, Bisht S P S, Ravi Kumar B V V, Raja Kumar V and Narendra A, International Journal of Comprehensive Pharmacy, 2011, 2, 1.

14. Dhiraj Kumar, Sreenivas S A, Himansu Bhusan Samal, Suddhasattya Dey, Priyanka Y, Journal of Pharmacy Research, 2011,4(6),1713.

15. Ashok Kumar A, Anil Kumar A and Gouri Sankar D, International Journal of Pharma and Bio Sciences, 2011, 2(2), 225

16. International Conference on Harmonization of Technical Requirements for Registration of Pharmaceuticals for Human Use (Nov. 6,) Validation of Analytical Procedures: Methodology, ICH Steering Committee, Geneva, Switzerland. 1996. 


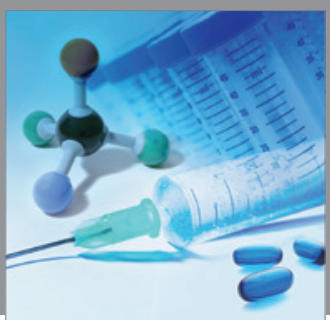

International Journal of

Medicinal Chemistry

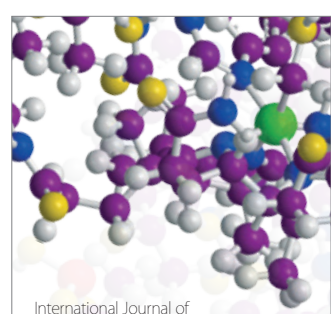

Carbohydrate Chemistry

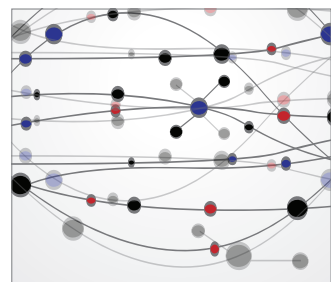

The Scientific World Journal
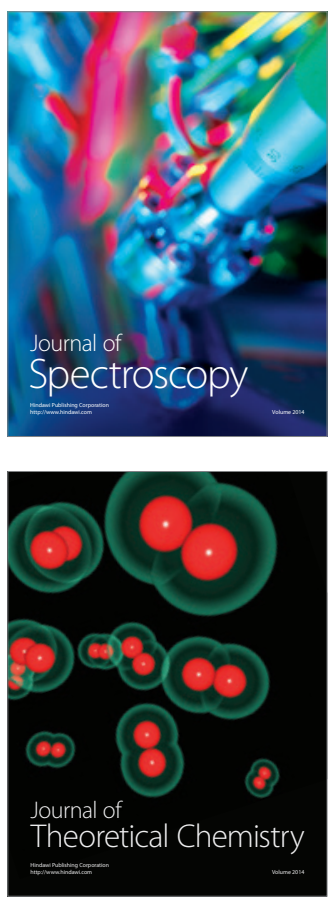
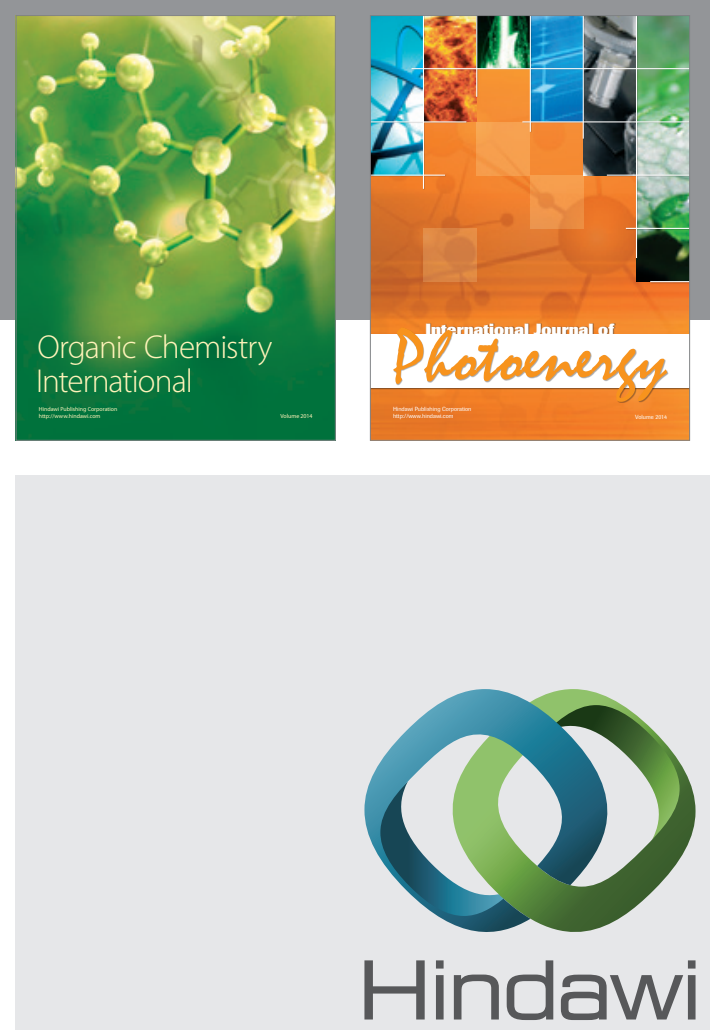

Submit your manuscripts at

http://www.hindawi.com
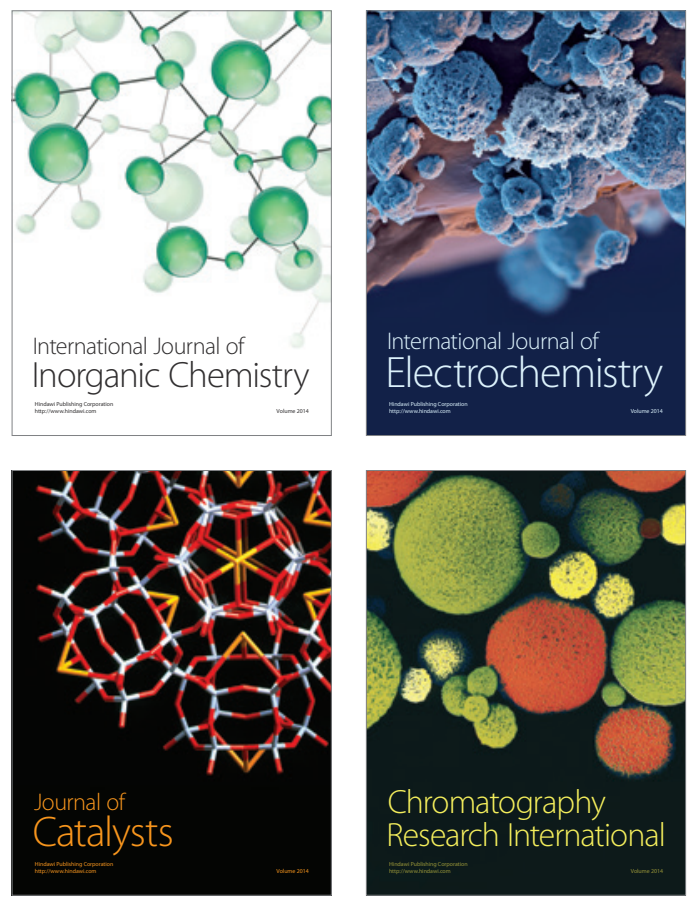
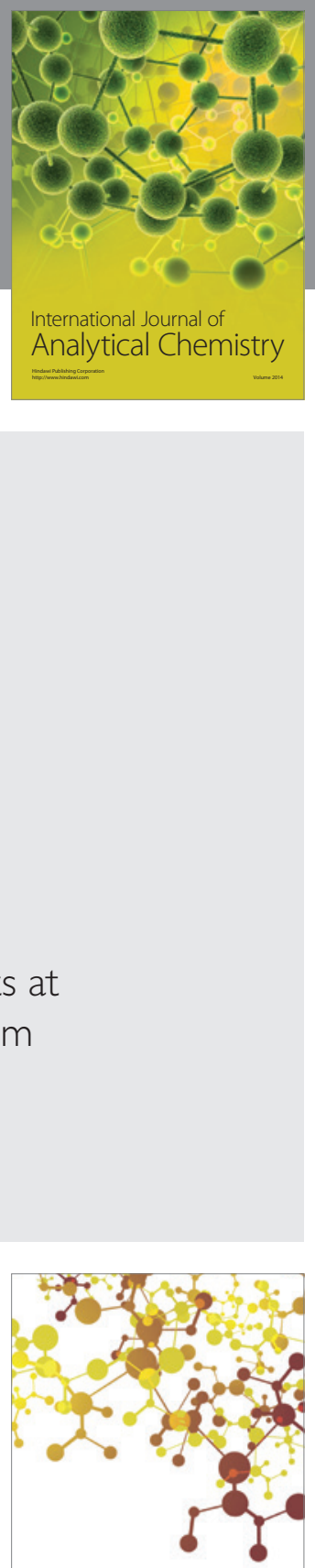

Journal of

Applied Chemistry
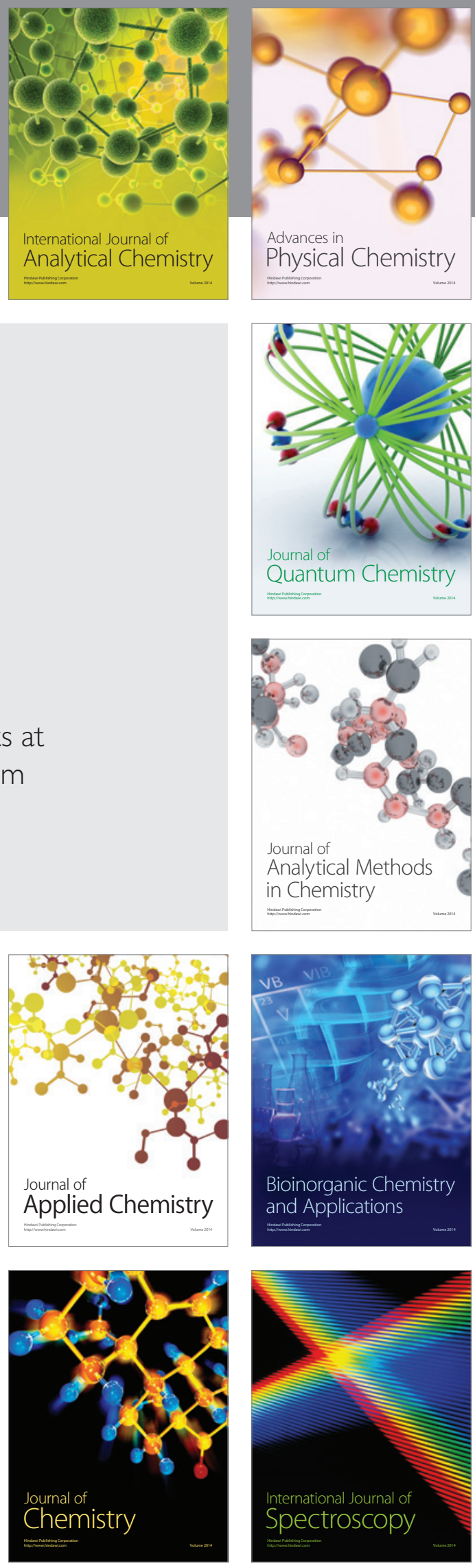